\title{
Performance of Laying Hens Fed Sorghum Based Diets Supplemented with Enzymes
}

Agunbiade, O. M., Onimisi, P. A. and Omage, J. J.

Department of Animal Science,

Ahmadu Bello University, Zaria Nigeria.

Corresponding author: onimisiphil@gmail.com

Abstract

GSM: +2348057228486

Sorghum is the primary alternative feedstuff for corn in some developed countries in the production of poultry. Thus, four hundred and fifty 32 weeks old Lohmann Brown laying hens were used in a study to evaluate the effect of replacing maize with sorghum with or without enzymes supplementation, on egg laying performance and egg quality characteristics of laying hens. Birds were distributed randomly into six dietary treatments with three replicates per treatment, each replicate had 25 birds with uniform initial group weights. The treatments included maize without enzymes (T1); sorghum without enzymes (T2); as controls respectively, while T3, T4, T5, and T6 contained sorghum based diets with phytase, protease, $G 2 G$, and a combination of protease and $G 2 G$ respectively. Laying performance, cost of production, and egg quality characteristics were determined for the period of the trial, $33-56$ weeks of age of the birds. All data obtained were subjected to analysis of variance, using the completely randomized design (CRD) and significant differences among treatment means were compared using the Tukey test. Significant $(p<0.05)$ differences were observed among dietary treatments but with no defined trend observed for egg production traits. Daily feed intake was significantly $(p<0.05)$ higher in maize control diet compared to the other treatments. Diets supplemented with phytase (T3), protease (T4), and combination of protease and roxazyme $G 2 G(T 6)$ had significantly $(p<0.05)$ better feed conversion ratio with T3 having the lowest value of 4.01 compared to the other treatments. For feed cost/dozen egg (N), Kg feed/dozen eggs, income above feed cost at N30 per egg, and income above control treatment; phytase (T3), protease (T4), roxazyme G2G (T5), and protease + roxazyme $G 2 G(T 6)$ diets in this study showed better performance than the control. Sorghum diet without enzyme had significantly $(p<0.05)$ least performance for egg number, Hen housed egg production (HHP) and hen day egg production (HDP) compared to the other treatments while sorghum diet with phytase had the highest value $(60.12 \mathrm{~g} /$ day) for average egg weight compared to the other treatments. Egg quality characteristics showed the best performance for dietary treatments supplemented with phytase (T3) in all the other parameters considered, apart from the albumen height, yolk diameter, and yolk index. It was concluded therefore, that sorghum with phytase and protease supplementations can be used in layers' diets as a substitute for maize for optimum egg production

Keywords: Laying hens, Sorghum, Enzymes, Egg Laying Performance, egg quality, cost analysis

\section{Introduction}

Sorghum is an important grain globally, and can be grown in areas of low rainfall and high summer temperatures. Sorghum is the fifth most important crop after wheat, rice, corn, and barley (Brydenet al., 2009). Also, sorghum is the primary alternative feedstuff for corn in the U.S., Central America, South America, and Asia and for wheat in Australia. It is used extensively by the Nigerian poultry industry, and if maize is scarce or out of season, or there is an 


\section{Laying performance of hens}

increase in price of maize, sorghum can constitute $100 \%$ of the cereal grain component of broiler diets. However, poultry nutritionists have observed that, broilers fed sorghum based diets have reduced performance compared to their counterparts fed maize or millet based diets. Subsequent studies have confirmed the concern of the industry and have shown that broilers on sorghum based diets have depressed feed efficiency and variable breast meat yields (Jacob et al., 1996).

Davis et al. (2003) reported that the metabolizable energy (ME) content of sorghum is comparable to that of maize and which is up to $13.79 \mathrm{MJ} / \mathrm{kg}$ and that it contains $12-14 \%$ CP. Sorghum contains $3,669 \mathrm{kcal} / \mathrm{kg}$ of $\mathrm{ME}, 7.8 \%$ crude protein and $10.6 \%$ crude fibre. It contains low levels of xanthophylls, linoleic acid, lysine, methionine and tryptophan (Lazaro and Favier, 2000). It is also low in calcium but high in phosphorus. Sorghum can be used to substitute maize in livestock feeding, and sorghum is also used in human food in various forms especially in the Northern part of Nigeria (Shaib et al., 1997). The use of sorghum in livestock feeding is limited by its contents of tannin (polyphenols), phytates, and cyanogenic glycosides (Awika et al., 2003). Sorghum varieties and hybrids differ in palatability and nutritional value, which may be associated with the level of tannin in the grain (Kim et al., 2000). This is probably why the efficiency of utilization of sorghum by poultry appears to be either the same as that of maize or 10 to $15 \%$ lower, apparently depending on processing method or the amount of tannin in the pericarp (Vinod et al., 2005), however, low tannin sorghum has been bred to improve its utilization in poultry. Tannins are a group of compounds that bind proteins, thus impairing protein digestion (Adewusi and Matthew, 1994).
The use of exogenous enzymes in poultry feed have been found to reduce effects of anti-nutritional factors and render nutrients more available for digestion and absorption. Cellulases ( $\beta$-glucanases), xylanases and associated enzymes, phytases, proteases, lipases, and galactosidases are some of the enzymes that have been used over the past years. Supplementing poultry diets with these exogenous enzymes can improve digestion of nutrients from feedstuffs, thereby decreasing feed costs and improving bird performance (Bedford, 2000; Elliot, 2002).The aim of this study was to determine the effect of enzymes supplementation on performance of laying hens fed sorghum based diets. The specific objective was to evaluate egg laying performance and egg quality characteristics of laying hens fed sorghum based diets supplemented with phytase (Ronozyme Phytase), protease (RonozymeProAct), and carbohydrases (Roxazyme G2G).

\section{Materials and methods}

\section{Location of the study}

The study was conducted at the Animal Science Teaching and Research Farm, Ahmadu Bello University, Zaria. Zaria is located within the Northern Guinea Savannah zone of Nigeria, latitude, $11^{0} 14^{\prime}$ $44^{\prime} \mathrm{N}$ and longitude $7^{\circ} 38^{\prime} 65^{\prime} \mathrm{E}$, at an altitude of $610 \mathrm{~m}$ above sea level. The climate is relatively dry, with a mean annual rainfall of $700-1400 \mathrm{~mm}$, occurring between the months of April and September (Ovimaps, 2015).

\section{Sources of birds and feedstuffs}

Lohmann Brown chicks were sourced from ZAM farms, and Kaura variety of Sorghum was purchased from the open market in Samaru, Zaria. The other ingredients for the experiment were purchased from 
Musphaza Agro Allied Investment Company Limited at Railway station market, Kaduna.

\section{Experimental design}

Four hundred and fifty 32 weeks old Lohmann Brown layers were distributed in a Completely Randomized Design into six treatments with 3 replicates per treatment, each replicate had 25 birds with all the replicates having uniform group weights. The experiment lasted from 32 - 56 weeks of age of the birds.

\section{Experimental diets}

Six experimental diets were formulated to includeT1 (maize based diet ascontrol); T2 (sorghum based diet without enzyme also as control); T3 (sorghum based diet with phytase); T4 (sorghum based diet with protease); T5 (sorghum based diet with G2G and T6 (sorghum based diet with a combination of Protease and G2G).

\section{Data collection}

Egg laying performance parameters measured included initial weight, final weight, feed intake, feed conversion ratio, hen day egg production (HDP), hen housed egg production (HHP), egg number, egg mass per hen and cost benefit analysis.

Parameters of egg quality were determined include egg weight, egg height, egg diameter, egg shell weight and egg shell thickness. The internal characteristics measured included albumen height, albumen diameter (width), albumen weight, yolk diameter, yolk height, and yolk weight.

Two eggs were picked at random per replicate at week eighteen, week twenty two, and week twenty six into laying. The eggs were weighed using an electronic top loading scale. The egg height and diameter were measured with electronic venire caliper. The egg shell thickness was measured with an electronic micrometer screw gauge. After cutting the eggs open to obtain the yolk and albumen, the egg shells were carefully washed with distilled water to remove adhering albumen, then dried at room temperature for 24 hours, and were weighed to obtain egg shell weight. The yolk diameter, yolk height and albumen height were determined with the electronic venire caliper immediately the eggs were broken carefully. Yolk index was calculated as yolk diameter divided by yolk height. The Haugh unit which is the most significant measure of egg quality was calculated from the measured height of albumen and weight of egg using the following formula as proposed by Haugh (1937).

$$
\mathrm{HU}=100 \log _{10}\left(\mathrm{~h}-1.7 \mathrm{~W}^{0.37}+7.6\right)
$$

Where; $\mathrm{HU}=$ Haugh unit

$\mathrm{h}=$ Observed height of the albumen in $\mathrm{mm}$

$\mathrm{W}=$ weight of egg in grams

The HU value normally ranges from $0-130$ and can be ranked as shown below:

AA: 72 or more

A: $71-60$

B:59-31

C: 30 or less

The higher the value, the better the quality of eggs.

\section{Data analysis}

All data generated were subjected to analysis of variance using a General Linear Model procedure, while Tukey Test was used to separate significant differences between means (SAS, 2001).

\section{Results and discussion}

Table 1 shows the laying performance of hens fed sorghum based diets at 33-56 weeks of age. Feed intake was significantly $(p<0.05)$ lower in sorghum plusphytase diet compared to the other treatments but highest for maize control diet which had $15.22 \mathrm{~kg} / \mathrm{bird}$ of total feed intake and a daily feed intake of $114.43 \mathrm{~g} / \mathrm{bird}$. Phytase, protease, and protease plus $\mathrm{G} 2 \mathrm{G}$ diets had better feed conversion ratio compared to the 


\section{Laying performance of hens}

other treatments, with $\mathrm{T} 3$ having the lowest value (4.01) which is the best compared to the other treatments. This also implies that the use of exogenous phytase in the poultry diet not only releases phosphorus from phytate, but also destroys the complexes of phytate formed together with other essential nutrients, thereby leading to higher nutritional value of the diet (Boling et al., 2000; Keshavarz, 2003; Panda et al., 2005).

Dietary treatment differs significantly for final weight, weight gain, egg number, average egg weight, egg mass, total feed intake, daily feed intake and feed conversion ratio. Protease, G2G and protease plus G2G diets had heavier final weights $(1903.33 \mathrm{~g} / \mathrm{bird}, 1900.00 \mathrm{~g} / \mathrm{bird}$, and $1933.33 \mathrm{~g} / \mathrm{bird}$ ) and weight gain $(503.33 \mathrm{~g} / \mathrm{bird}, 526.67 \mathrm{~g} / \mathrm{bird}$, and $563.33 \mathrm{~g} / \mathrm{bird}$ ) above the Maize control diet. Enzymes supplementation sustained and improved body condition of birds. This is also an advantage to the farmer and an increased source of income when birds are sold as spent layers at the end of laying period.

The egg number was significantly higher in maize control diet compared to Sorghum control diet, but similar to phytase, protease, G2G, and protease plus G2G diets. Phytase diet was similar with the other treatments in terms of egg number, apart from Sorghum control diet that had the lowest value for egg number. G2G diet had the lowest average egg weight compared to the other treatments, which may suggest that, the roxazyme G2G did not have a significant effect on the egg weight of the birds. Sorghum supplemented with Phytase had the best value (2967.50 $\mathrm{g} / \mathrm{bird}$ ) for egg mass and was significantly $(p<0.05)$ higher than all the other treatments.

Generally, the use of sorghum without enzyme supplementation recorded the least overall performance for egg number, egg mass, and feed to gain ratio. However, supplementation of sorghum based diet with enzymes, particularly phytase in poultry feeds led to improved performance of birds. This agrees with earlier report that microbial phytase increased phosphorus availability giving rise to increased feed conversion efficiency, egg production, egg weight and egg shell quality (Jalal et al., 2007).

Table 1: Laying Performance of Hens fed Sorghum Based Diets supplemented with enzymes

\begin{tabular}{|c|c|c|c|c|c|c|c|}
\hline \multirow[b]{2}{*}{ Parameters (\%) } & \multirow[b]{2}{*}{$\begin{array}{l}\text { T1 } \\
\text { (Maize } \\
\text { Control) }\end{array}$} & \multirow[b]{2}{*}{$\begin{array}{l}\mathrm{T} 2 \\
\text { (Sorghum } \\
\text { Control) }\end{array}$} & \multicolumn{4}{|c|}{ Dietary Treatments } & \multirow[b]{2}{*}{ SEM } \\
\hline & & & $\begin{array}{l}\mathrm{T} 3 \\
\text { (Sorghum } \\
\text { +Phytase) }\end{array}$ & $\begin{array}{l}\mathrm{T} 4 \\
\text { (Sorghum } \\
\text { +Protease) }\end{array}$ & $\begin{array}{l}\text { T5 } \\
\text { (Sorghum } \\
+\mathrm{G} 2 \mathrm{G})\end{array}$ & $\begin{array}{l}\text { T6 (Sorghum } \\
+ \text { Protease } \\
+\mathrm{G} 2 \mathrm{G} \text { ) }\end{array}$ & \\
\hline Initial weight (g/bird) & $1416.67^{\mathrm{a}}$ & $1356.67^{b}$ & $1343.33^{\mathrm{b}}$ & $1400.00^{\mathrm{a}}$ & $1373.33^{\mathrm{b}}$ & $1370.00^{\mathrm{b}}$ & 18.13 \\
\hline Final weight (g/bird) & $1760.0^{\mathrm{b}}$ & $1766.67^{\mathrm{b}}$ & $1773.33^{\mathrm{b}}$ & $1903.33^{\mathrm{a}}$ & $1900.00^{\mathrm{a}}$ & $1933.33^{\mathrm{a}}$ & 35.58 \\
\hline Weight gain (g/bird) & $343.33^{c}$ & $410.00^{\mathrm{b}}$ & $430.00^{\mathrm{b}}$ & $503.33^{\mathrm{a}}$ & $526.67^{\mathrm{a}}$ & $563.33^{\mathrm{a}}$ & 47.21 \\
\hline Egg number/bird & $48.00^{\mathrm{a}}$ & $38.00^{\mathrm{b}}$ & $49.00^{\mathrm{a}}$ & $45.00^{\mathrm{ab}}$ & $43.00^{\mathrm{ab}}$ & $47.00^{\mathrm{a}}$ & 4.00 \\
\hline $\begin{array}{l}\text { Average egg weight } \\
\text { (g/bird) }\end{array}$ & $59.05^{\mathrm{a}}$ & $58.83^{\mathrm{a}}$ & $60.12^{\mathrm{a}}$ & $59.07^{\mathrm{a}}$ & $57.50^{\mathrm{b}}$ & $59.39^{\mathrm{a}}$ & 0.95 \\
\hline Egg mass (g/bird) & $2822.90^{b}$ & $2191.20^{\mathrm{d}}$ & $2967.50^{\mathrm{a}}$ & $2644.50^{\mathrm{b}}$ & $2495.90^{c}$ & $2815.90^{\mathrm{b}}$ & 186.27 \\
\hline $\begin{array}{l}\text { Total feed intake } \\
\text { (Kg/bird) }\end{array}$ & $15.22^{\mathrm{a}}$ & $13.96^{\mathrm{ab}}$ & $13.04^{\mathrm{b}}$ & $13.36^{\mathrm{ab}}$ & $13.20^{\mathrm{ab}}$ & $13.40^{\mathrm{ab}}$ & 2.00 \\
\hline $\begin{array}{l}\text { Daily feed intake } \\
\text { (g/bird) }\end{array}$ & $114.43^{\mathrm{a}}$ & $104.94^{\mathrm{b}}$ & $98.04^{\mathrm{c}}$ & $100.47^{b}$ & $99.28^{\mathrm{b}}$ & $100.74^{\mathrm{b}}$ & 4.49 \\
\hline Feed conversion ratio & $4.94^{\mathrm{b}}$ & $5.91^{\mathrm{c}}$ & $4.01^{\mathrm{a}}$ & $4.61^{\mathrm{ab}}$ & $4.80^{\mathrm{b}}$ & $4.37^{\mathrm{ab}}$ & 0.32 \\
\hline
\end{tabular}




\section{Agunbiade, Onimisi and Omage}

The cost analysis of laying chickens fed sorghum based diets at 33-56 weeks of age is shown in Table 2. Dietary treatments had significant $(p<0.05)$ effect on feed cost $(\mathrm{N} / \mathrm{kg}), \mathrm{kg}$ feed/dozen eggs, feed cost per dozen eggs (N/dozen eggs), income above feed cost at N30/egg, income above control treatment (T1), \%HHP, \%HDP and mortality.

Phytase, protease and $\mathrm{G} 2 \mathrm{G}$ diets had the best performance and were similar for feed cost per dozen eggs (N152.02, N158.05 and N156.29), Income above feed cost at $\mathrm{N} 30 /$ egg (N17.33, N16.83 and N16.98), income above control treatment (N2.14, $\mathrm{N} 1.63$ and $\mathrm{N} 1.78)$ and $\% \mathrm{HHP}(63.57,59.53$ and 57.79). Protease plus G2G diet was similar to Phytase, Protease and G2G diets for income above feed cost at N30/egg, income above control treatment and \%HHP. Phytase diet had the highest numerical values for income above feed cost at N30/egg (N17.33), income above control treatment (N2.14) and \%HDP. The \%HHP and $\% \mathrm{HDP}$ were significantly $(\mathrm{p}<0.05)$ lower in the sorghum control (T2) compared to other treatments. Protease and Protease plus G2G diets recorded the least mortality compared to all the other dietary treatments.

Generally, the cost of enzyme increased the cost per kilogram of diets containing it. However, supplementing the diets with phytase, protease and roxazyme $\mathrm{G} 2 \mathrm{G}$ resulted in cheaper cost/kilogram weight gain compared to the un-supplemented diet. Also, it increases the income accruing to the farmer compared to the control treatment. This outcome favours inclusion of the enzymes, since the desire of every investor is to maximize profit and productivity at the least cost. Diets containing the supplemented enzymes showed positive cost benefits. Similar pattern was observed by various researchers (Sohail et al., 2003 and Scheideler et al., 2005) who fed barley supplemented with Allzyme and Kemzyme. It can therefore be inferred that the use of these exogenous enzymes, most especially phytase did not only make available the nutrients bound by the antinutritional factors in sorghum based diets, but also has a significant effect on the economics and cost analysis of laying chickens. And therefore, with proper management practices, can lead to a better and higher profitability for egg producers.

Table 2: Cost analysis of production in hens fed sorghum based diets supplemented with enzymes

\begin{tabular}{|c|c|c|c|c|c|c|c|}
\hline \multirow[b]{2}{*}{ Parameters $(\%)$} & \multicolumn{6}{|c|}{ Dietary Treatments } & \multirow[b]{2}{*}{ SEM } \\
\hline & $\begin{array}{l}\text { T1 } \\
\text { (Maize } \\
\text { Control) }\end{array}$ & $\begin{array}{l}\mathrm{T} 2 \\
\text { (Sorghum } \\
\text { Control) }\end{array}$ & $\begin{array}{l}\text { T3 } \\
\text { (Sorghum } \\
\text { +Phytase) }\end{array}$ & $\begin{array}{l}\mathrm{T} 4 \\
\text { (Sorghum } \\
\text { +Protease) }\end{array}$ & $\begin{array}{l}\text { T5 } \\
\text { (Sorghum } \\
+\mathrm{G} 2 \mathrm{G})\end{array}$ & $\begin{array}{l}\text { T6 (Sorghum } \\
\text { +Protease } \\
+\mathrm{G} 2 \mathrm{G})\end{array}$ & \\
\hline Feed cost $(\# / k g)$ & $60.55^{\mathrm{a}}$ & $62.97^{\mathrm{b}}$ & $64.07^{\mathrm{d}}$ & $64.07^{\mathrm{d}}$ & $63.77^{\mathrm{c}}$ & $64.87^{\mathrm{e}}$ & 0.01 \\
\hline $\mathrm{Kg}$ feed/dozen eggs & $2.93^{\mathrm{c}}$ & $2.62^{\mathrm{b}}$ & $2.37^{\mathrm{a}}$ & $2.47^{\mathrm{a}}$ & $2.45^{\mathrm{a}}$ & $2.48^{\mathrm{b}}$ & 0.07 \\
\hline $\begin{array}{l}\text { Feed cost }(\sharp / \text { dozen } \\
\text { eggs })\end{array}$ & $177.66^{\mathrm{c}}$ & $165.20^{\mathrm{b}}$ & $152.02^{\mathrm{a}}$ & $158.05^{\mathrm{a}}$ & $156.29^{\mathrm{a}}$ & $160.79^{b}$ & 4.65 \\
\hline $\begin{array}{l}\text { Income above feed } \\
\text { cost at } \$ 30 / \mathrm{Eg}\end{array}$ & $15.19^{c}$ & $16.23^{b}$ & $17.33^{\mathrm{a}}$ & $16.83^{\mathrm{a}}$ & $16.98^{\mathrm{a}}$ & $16.60^{\mathrm{a}}$ & 0.39 \\
\hline $\begin{array}{l}\text { Income (N) Above } \\
\text { Control Treatment } \\
\text { (T1) }\end{array}$ & $0.00^{\mathrm{d}}$ & $1.04^{\mathrm{c}}$ & $2.14^{\mathrm{a}}$ & $1.63^{\mathrm{b}}$ & $1.78^{\mathrm{a}}$ & $1.41^{\mathrm{b}}$ & 0.46 \\
\hline $\operatorname{HDP}(\%)$ & $69.54^{\mathrm{a}}$ & $52.83^{c}$ & $70.05^{\mathrm{a}}$ & $60.33^{b}$ & $60.12^{\mathrm{b}}$ & $64.74^{\mathrm{b}}$ & 3.93 \\
\hline HHP (\%) & $63.57^{\mathrm{a}}$ & $49.88^{b}$ & $63.57^{\mathrm{a}}$ & $59.53^{\mathrm{a}}$ & $57.79^{a}$ & $63.11^{\mathrm{a}}$ & 3.32 \\
\hline Mortality (\%) & $8.00^{c}$ & $5.00^{\mathrm{b}}$ & $5.00^{\mathrm{b}}$ & $1.00^{\mathrm{a}}$ & $4.00^{\mathrm{b}}$ & $2.00^{\mathrm{a}}$ & 2.00 \\
\hline
\end{tabular}




\section{Laying performance of hens}

The result of the egg quality parameters of laying chickens fed sorghum supplemented with enzymes is presented in Table 3. Dietary treatments differed significantly $(p<0.05)$ for both internal and external parameters except in shell weight which showed no significant $(\mathrm{p}>0.05)$ differences across the treatments. Phytase diet resulted in higher values for external quality parameters (egg weight, egg height, shell weight, shell thickness and egg diameter). No defined trend was observed for the internal quality parameters (albumen height, albumen diameter, albumen weight, yolk height, yolk diameter, yolk weight, yolk index and Haugh unit). All the other treatments apart from Protease diet, were similar for egg weight and egg height. Protease and G2G diets were higher and similar to the Maize control diet (T1) for yolk index. Yolk weight was significantly higher in Maize control diet (15.78g) and similar with Sorghum control, Phytase and Protease diets. Haugh unit was numerically higher in Protease plus G2G diet (91.45) and was comparable with Sorghum control, Phytase and G2G diets. Protease plus G2G diet was comparable with the control diet in the internal quality parameters assessment for albumen diameter, albumen weight and yolk height.

The observed ranges of $58.47 \mathrm{~g}-62.80 \mathrm{~g}$ for egg weight were higher than the values reported by Olugbemi et al. (2010). Differences in the values of egg weight obtained could be as a result of the enzyme supplementation, which enhance nutrient utilization (Kakengi et al. 2007). Also the significant differences obtained in this study were at variance with the reported values of Tuleun et al. (1998) who observed no difference. Ranges of $43.28-44.07 \mathrm{~mm}$ for egg diameter observed were comparatively higher than the values obtained by Oyewumi et al. (2010), and also with those of Egahi et al. (2007), who reported the same ranges of values. Albumen heights obtained in this study were higher than the values reported by Tuleun et al. (1998) and Aboonajmi et al. (2010).

Variations in egg quality parameters (internal and external) are influenced by plethora of factors. Hence, comparing observed results with previous studies may not prove or disprove much. However, thickness of albumen is indicative of viscosity and freshness of the egg. Albumen weight and yolk weight ranges of $34.88 \mathrm{~g}-$ $38.93 \mathrm{~g}$ and $14.70 \mathrm{~g}-15.78 \mathrm{~g}$ in this study were comparatively higher than the values reported by Egahi et al. (2007) and Aboonajmi et al. (2010). However, the results obtained are in agreement with the findings of Oyewumi et al. (2010) on enzyme supplementation in laying hens. Observed significant difference across dietary treatments with better performance in enzyme supplementation with sorghum based diets were at variance with the observation of Egahi et al. (2007), who reported no significant dietary effect on egg quality traits. Observations on shell thickness $(0.43-0.48 \mathrm{~mm})$ were lower than those reported by Oyewumi et al. (2010). Haugh Unit (HU) ranges of 86.90 - 91.45 were comparatively higher than values reported by Egahi et al. (2007) and Aboonajmi et al. (2010). These variations may be due to the age of the birds, and also as a result of the level of the calcium content of the diets fed and the available phosphorus. As an indicator of egg freshness, HU values obtained in this result were high but significant dietary influences existed, contradicting the report of no significant differences by Oyewumi et al. (2010). 
Agunbiade, Onimisi and Omage

Table 3: Egg Quality Characteristics of Hens Fed Sorghum based diets supplemented with enzymes at 33-52 Weeks of Age

\begin{tabular}{|c|c|c|c|c|c|c|c|}
\hline \multirow[b]{2}{*}{ Parameters $(\%)$} & \multicolumn{6}{|c|}{ Dietary Treatments } & \multirow[b]{2}{*}{ SEM } \\
\hline & $\begin{array}{l}\text { T1 } \\
\text { (Maize } \\
\text { Control) }\end{array}$ & $\begin{array}{l}\text { T2 } \\
\text { (Sorghum } \\
\text { Control) }\end{array}$ & $\begin{array}{l}\text { T3 } \\
\text { (Sorghum } \\
\text { +Phytase) }\end{array}$ & $\begin{array}{l}\mathrm{T} 4 \\
\text { (Sorghum } \\
\text { +Protease) }\end{array}$ & $\begin{array}{l}\text { T5 } \\
\text { (Sorghum } \\
+\mathrm{G} 2 \mathrm{G} \text { ) }\end{array}$ & $\begin{array}{l}\text { T6 (Sorghum } \\
+ \text { Protease } \\
+ \text { G2G) }\end{array}$ & \\
\hline \multicolumn{8}{|l|}{ External Quality } \\
\hline Egg Weight (g) & $61.65^{\mathrm{a}}$ & $61.33^{\mathrm{a}}$ & $62.34^{\mathrm{a}}$ & $58.47^{\mathrm{b}}$ & $61.18^{\mathrm{a}}$ & $62.80^{\mathrm{a}}$ & 1.00 \\
\hline Egg Height (mm) & $56.55^{\mathrm{a}}$ & $56.89^{\mathrm{a}}$ & $57.20^{\mathrm{a}}$ & $55.94^{\mathrm{b}}$ & $57.28^{\mathrm{a}}$ & $56.94^{\mathrm{a}}$ & 0.51 \\
\hline Shell Weight (g) & 6.08 & 6.07 & 5.92 & 5.92 & 6.20 & 6.23 & 0.21 \\
\hline $\begin{array}{l}\text { Shell Thickness } \\
(\mathrm{mm})\end{array}$ & $0.43^{b}$ & $0.45^{\mathrm{a}}$ & $0.45^{\mathrm{a}}$ & $0.45^{\mathrm{a}}$ & $0.47^{\mathrm{a}}$ & $0.48^{\mathrm{a}}$ & 0.02 \\
\hline Egg Diameter (mm) & $43.38^{\mathrm{b}}$ & $43.89^{\mathrm{a}}$ & $44.07^{\mathrm{a}}$ & $43.28^{\mathrm{b}}$ & $43.61^{\mathrm{b}}$ & $43.96^{\mathrm{a}}$ & 0.23 \\
\hline \multicolumn{8}{|l|}{ Internal Quality } \\
\hline $\begin{array}{l}\text { Albumen Height } \\
(\mathrm{mm})\end{array}$ & $7.61^{b}$ & $8.29^{\mathrm{a}}$ & $7.88^{\mathrm{b}}$ & $7.66^{\mathrm{b}}$ & $7.88^{b}$ & $8.51^{\mathrm{a}}$ & 0.18 \\
\hline $\begin{array}{l}\text { Albumen Diameter } \\
(\mathrm{mm})\end{array}$ & $70.17^{\mathrm{a}}$ & $69.30^{\mathrm{a}}$ & $70.48^{a}$ & $66.28^{b}$ & $67.93^{b}$ & $68.59^{a}$ & 1.01 \\
\hline Albumen Weight (g) & $38.21^{\mathrm{a}}$ & $36.52^{\mathrm{b}}$ & $38.44^{\mathrm{a}}$ & $34.88^{b}$ & $37.11^{\mathrm{a}}$ & $38.93^{\mathrm{a}}$ & 0.92 \\
\hline Yolk Height (mm) & $16.98^{\mathrm{a}}$ & $17.41^{\mathrm{a}}$ & $17.02^{\mathrm{a}}$ & $16.58^{b}$ & $16.81^{\mathrm{b}}$ & $16.97^{\mathrm{a}}$ & 0.24 \\
\hline Yolk Diameter (mm) & $41.85^{\mathrm{a}}$ & $41.56^{\mathrm{a}}$ & $40.16^{\mathrm{b}}$ & $40.80^{\mathrm{b}}$ & $42.04^{\mathrm{a}}$ & $40.39^{b}$ & 0.50 \\
\hline Yolk Weight (g) & $15.78^{a}$ & $15.58^{\mathrm{a}}$ & $15.25^{\mathrm{a}}$ & $15.52^{\mathrm{a}}$ & $14.70^{\mathrm{b}}$ & $14.96^{\mathrm{b}}$ & 0.36 \\
\hline Yolk Index & $2.47^{\mathrm{a}}$ & $2.39^{\mathrm{b}}$ & $2.36^{\mathrm{b}}$ & $2.46^{\mathrm{a}}$ & $2.50^{\mathrm{a}}$ & $2.38^{\mathrm{b}}$ & 0.04 \\
\hline Haugh Unit & $86.90^{\mathrm{b}}$ & $90.78^{a}$ & $88.59^{a}$ & $88.02^{\mathrm{b}}$ & $88.51^{\mathrm{a}}$ & $91.45^{\mathrm{a}}$ & 1.55 \\
\hline
\end{tabular}

\section{Conclusion}

The result showed that supplementation of diets with protease and phytase improved the utilization of sorghum for egg laying performance. There was positive and practical merits for the replacement of maize with sorghum supplemented with phytase in the nutrition of laying hens.

\section{References}

Aboonajmi, A., Akram, T., Nishizu, N., Kondo, S. K. and Setarehdan, A. 2010. An ultrasound based technique for the determinationof poultry egg quality. Resource Agricultural Engineering. 56(1): 26-32.

Adewusi, S. R. A. and Matthew, O. I. 1994. Nutritional evaluation of spent grains from sorghum malts and maize grit. Plant foods for human nutrition (for m e r $1 \mathrm{y}$ QualitasPlantarum), 46:41-51.
A.O.A.C. 1995. Association of Official and Analytical chemists. $15^{\text {th }}$ Edition William Press, Richard Virginia. U.S.A.

Awika, J. M., Dykes, L., Gu, L., Rooney, L. W. and Prior, R. L. 2003. Processing of sorghum and sorghum products alters procyanidin oligomer and polymer distribution and content. Journal of Agricultural Food Chemistry, 51: 5516- 5521.

Bedford, M. R. 2000. Exogenous enzymes in monogastric nutrition- their current value and future benefits. Animal Feed Science and Technology, 86, 1, 1-3.

Boling, S. D., Douglas, M. W., Shirley, R. B., Parsons, C. M. and Koelkebeck, K. W. 2000.The effect of various dietary levels of phytaseand available phosphorus on performance of laying hens. Poultry Science, 79:535-538. 
Bryden, W. L., Selle, P. H., Cadogan, D. J., Li, X., Muller, N. D., Jordan, D. R., Gidley, M. J. and Hamilton, W. D. 2009. A review of the nutritive value of sorghum in broilers. Rural Industry Resource. Kingston, Australia.

Davis, A. J., Dale, N. M and Ferreira, F. J. 2003. Pearl millet as an alternative feed ingredient in broiler diets. Journal of Applied Poultry Research, 12: 137-144.

Egahi, J. O., Ioryue, C. T. and Dim, N. I. 2007. The Effect of age of bird on egg quality characteristics of Lohman brown layers in Makurdi. Proceedings of the $36^{\text {th }}$ Annual Conference, Nigerian Society for Animal Production. $13^{\text {th }}-16^{\text {th }}$ March 2011. University of Abuja, Nigeria.pp59-61.

Elliot, M. 2002. Enzyme Use in Commercial Layer Production. Proceedings of the Multi- State Poultry Meeting, Indianapolis, Indiana, USA.

Jacob, J. P., Mitaru, B. N., Mbugua, P. N. and Blair, R. 1996. The feeding value of Kenyan sorghum, sunflower seed cake, and sesame seed cake for broilers and layers. Animal. Feed Technology, 61:4146.

Jalal, M. A., Scheideler, S. E. and Pierson, E. 2007. Strain responses of laying hens to varying dietary energy with and without enzyme supplementation. Journal of Applied Poultry Resource, 16:289295.

Kakengi, A. M., Kaijage, J. T., Sarwatt, S. V., Mutayoba, S. K., Shem, M. N. and Fujihara, T. 2007. Effects of Moringa oleifera leaf meal as a substitute for sunflower seed meal on the performance of laying hens in Tanzania. Livestock Research for Rural Development 19(8):1214

Keshavarz, K. 2003. The effect of different levels of non phytatephosphorus with and without phytase on performance of four strains oflaying hens. Poultry Science, 82: 71-91.

Kim, I. H., Cao, H., Hamcock, J. D., Park, J. S. and Li, D. F. 2000. Effects of processing and genetics on the nutritional value of sorghum in chicks and pigs. AsianAustralian Journal of Animal Science, 13: 1337-1344.

Lazaro, E. L. and Favier, J. F. 2000. Alkali de-branning of sorghum and millet. Cereal Chem., 77 (6):717720

Ovimaps. 2015. Ovi location map: Ovi earth imagery date; July $5^{\text {th }}$.

Oyewumi, S. O., Amao, S. R. and Olatunde, A. K. 2010. Egg Quality and Haematological Characteristics of Layers Fed Cassava Grit Meal. Proceedings ofthe $36^{\text {th }}$ Annual Conference of the Nigerian Society for Animal Production. 13- 16 ${ }^{\text {th }}$ March, 2011, University Of Abuja, Nigeria.pp234-237.

Panda, A. K., Rama, Rao, S. V., Raju, M. V. L. N. and Bhanja, S. K. 2005. Effect of microbial phytase on production performance of whiteleghorn layers fed on a diet low in non-phytate phosphorus. BritishPoultry Science, 46:464469.

S.A.S. $\quad 9.0$ 2001. Statistical analysis system. SAS/STAT User's guide version 6. Vol 2, SAS Inst-Inc. carry, N.C 846. 
Scheideler, S., Jalal, M. and Weber, T. 2005. Testing the optimum blend of fine: large particle size limestone and dietary calcium level for the Hy Line W-36 Mineral nutrition and W-98 strains of White Leghorn hens. Poultry Science Association Annual Meeting. Abstract book, 121.

Shaib, B., Aliyu, A. and Bakshi, J. S. 1997. Nigerian National Agricultural Research Strategy Plan, 19962010. Department of Agricultural Science, Federal Ministry of Agriculture and Mineral Resources, Abuja, Nigeria: 1-45.
Sohail, S. S., Bryant, M. M., Roland, D. A., Apajalahti, J. H. A. and Pierson, E. E. M. 2003. Influence of Avizyme 1500 on Performance of Commercial Leghorns. Journal of Applied Poultry Research, P. 284-290.

Tuleun, C. D., Njoku, P. C. and Yaakugh, I. D. I. 1998. The performance of $\mathrm{p} \mathrm{u} 11 \mathrm{e} \mathrm{t} \mathrm{ch} \mathrm{i} \mathrm{c} \mathrm{s} \mathrm{f} \mathrm{e} \mathrm{d}$ Rox a z y me ${ }^{\circledR} .3{ }^{r d} A S A N$ Conference, Lagos. Pp 74-76.

Received $8^{\text {th }}$ December, 2016 Accepted: $4^{\text {th }}$ March, 2017 